\title{
Assessment of per se performance of tomato (Solanum lycopersicum L.) hybrids TNAU Tomato Hybrid CO4 and Arka Vishesh in Salem District of Tamil Nadu
}

\author{
Malathi, G' ${ }^{1}$, M.Vijayakumar ${ }^{2}$, P.Kohila ${ }^{3}$, M.Malarkodi ${ }^{4}$ and S.Suganyakanna $^{5}$ \\ ${ }^{1}$ Assistant Professor (Hort.), Krishi Vigyan Kendra, Sandhiyur, Salem, Tamil Nadu \\ ${ }^{2}$ Associate Professor (Agron.), Krishi Vigyan Kendra, Sandhiyur, Salem, Tamil Nadu \\ ${ }^{3}$ Assistant Professor (V\&AS), Krishi Vigyan Kendra, Sandhiyur, Salem, Tamil Nadu \\ ${ }^{4}$ Assistant Professor (SS\&AC), Krishi Vigyan Kendra, Sandhiyur, Salem, Tamil Nadu \\ ${ }^{5}$ Assistant Professor (Agrl Ento.), Krishi Vigyan Kendra, Sandhiyur, Salem, Tamil Nadu
}

\begin{abstract}
In Salem district of Tamil Nadu, tomato is cultivated in an area of 526ha in Panamarathupatti block. The major villages cultivating tomato are Panamarathupatti, Kammalapatti, Thumbalpatti, Mallur, Nalikkalpatti etc., Most of the farmers are cultivating private tomato hybrids with lesser productivity and yield loss due to diseases like leaf curl, early and late blight and bacterial wilt was upto $30 \%$. Hence it is proposed to conduct an on farm trial to assess the per se performance of tomato hybrids with high yield and multiple disease resistance like TNAU Tomato Hybrid CO4 and Arka Vishesh. A field experiment was conducted as an on farm trial in five different locations of Panamarathupatti block of Salem district during Kharif season of 2019 in tomato using hybrids IIHR hybrid Arka Vishesh and TNAU Tomato Hybrid CO 4 with Sivam private hybrid as check hybrid. TNAU Tomato Hybrid CO 4 recorded an average yield of $95 \mathrm{t} / \mathrm{ha}$ and Arka Vishesh recorded an average yield of around $87 \mathrm{t} / \mathrm{ha}$. The private hybrid Sivam recorded an yield of 62 t/ha. TNAU Tomato Hybrid CO 4 recorded more average number of fruits per cluster (5-6) and higher fruit yield per plant (2.5 to $2.75 \mathrm{~kg}$ ) when compared to Arka Vishesh with average number of fruits per cluster (4-5) and higher fruit yield per plant $(2.25$ to $2.50 \mathrm{~kg}$ ). The seed cost of the private variety grown by the farmer is higher and the hybrids such as TNAU CO4 and IIHR hybrid Arka Vishesh performed better with regard to higher cost benefit ratio (BCR for TNAU Tomato Hybrid CO 4 is 1:3.81 and for Arka Vishesh 1:3.41). But the market preference for COTH4 is comparatively higher due to the large sized fruits with green shoulder at breaker stage with more acidity $(0.7 \%)$ which enhances the consumer preference in the market. In general the consumers prefer COTH4 hybrid rather than Arka Vishesh hybrid and hence marketability is also comparatively easier and better in TNAU Tomato Hybrid CO 4.
\end{abstract}

Keywords-Tomato, Solanum lycopersicum L., hybrids, performance, on farm trial

\section{INTRODUCTION}

Tomato (Solanum lycopersicum L.) belongs to the family Solanaceae. Tomato has acquired the status of World's most popular vegetable crop due to its wider adaptability to various agro climatic conditions (Gupta et al., 2015). Tomato is a perennial plant but commonly cultivated as an annual (Rick, 1978) and ranks second to potato in many countries. In Tamil Nadu, tomato is cultivated in an area of 29,000 hectares with a production of around one million tonnes and productivity of 30.51 tonnes per hectare. Tomato is considered as protective food crop because of having rich in mineral, vitamins and organic acids. It is an important source of lycopene, ascorbic acid and carotene valued for their colour, flavour and antioxidant properties. The increasing consumption of tomato makes it, a high value crop for generating income to the farmers. It is an important crop both for production and industry point of view, there is a

(1) IARJSET This work is licensed under a Creative Commons Attribution 4.0 International License 


\title{
International Advanced Research Journal in Science, Engineering and Technology
}

\author{
Vol. 8, Issue 8, August 2021
}

\section{DOI: $10.17148 / I A R J S E T .2021 .8881$}

necessity to improve the productivity per unit area to achieve the increased production from a limited land. Generally diverse parents are expected to give high hybrid vigour and it is also often possible to combine desired alleles in regular fashion without waiting for longer term (Shankar et al., 2015). Hence, usually hybrids show better fitness and breeding value than their parents. Higher yield and better fruit quality are universally desired (Triveni et al., 2017 and Vilas et al. 2015).

In Salem district, the area under horticultural crops is 39765 ha and area under tomato cultivation is around 3000 ha in the year 2019-20. Private hybrids are ruling in the market. Most of the farmers are cultivating private tomato hybrids with lesser productivity and yield loss due to diseases like leaf curl, early and late blight and bacterial wilt was upto $30 \%$. Hence, an investigation is needed to assess the performance of high yielding tomato hybrids in Salem district.

\section{EXPERIMENTAL METHODS OR METHODOLOGY}

The experimental material consists of three different hybrids of tomato namely, TNAU Tomato hybrid $\mathrm{CO} 4$ (CTH 4), Arka Vishesh and Sivam hybrid.

CTH 4 is released from Horticultural College and Research Insititute, Tamil Nadu Agricultural University, Coimbatore and the special charectistics of CTH 4 is a F1 hybrid of LE 1226 X LE 1249, in which fruits are flat round with thick pericarp $(5.84 \mathrm{~mm})$, the fruits have green shoulder at breaker stage which turns to red colour at ripening. Fruits are borne in clusters of 5-6, with an average fruit weight of $75.3 \mathrm{~g}$. The hybrid has long harvesting period with $20-22$ harvests in 150 days with a yield of $2.94 \mathrm{~kg}$ per plant. It is having a capacity of yielding $92.3 \mathrm{t} / \mathrm{ha}(27.31 \%$ increase over TNAU tomato hybrid CO3 and $40.91 \%$ over Lakshmi) with ascorbic acid content: $26.13 \mathrm{mg} / 100 \mathrm{~g}$ and TSS: $6.1 \mathrm{o}$ brix and titrable acidity: $0.70 \%$.

Arka Vishesh is a F1 hybrid released from Indian Institute of Horticultural Research, Bengaluru and its special charecteristics are It has the yield potential of 75-80 t/ha. It is suitable for processing into puree, paste, ketchup, sauce, tomato crush. TSS: 4- $4.6^{0}$ Brix, colour value of crushed tomato juice (a/b, Hunter Lab scale): $1.98-2.12$, average fruit weight: $70-75 \mathrm{gm}$, acidity of crushed tomato juice: $0.32-0.36, \mathrm{pH}: 4.21-4.41$, lycopene content: $8.5-10.5 \mathrm{mg} / 100 \mathrm{~g}$, lycopene content in tomato paste: $14.14 \mathrm{mg} / 100 \mathrm{~g}$, firmness: $4.09-5.41 \mathrm{~kg} / \mathrm{cm}^{2}$, seed content 0.4 to 0.5 and peel content: 5.96 .

Sivam is a private semi determinate hybrid from Hyveg Company and it is tall determinate to semi determinate plants with good foliage cover and vigour. Days to first harvest 62-67 days.Flat round fruits with green with very firm structure and acidic taste. Colour of the fruit is deep red with a average weight of 100-120 $\mathrm{g}$ and it is having intermediate resistance to tomato leaf curl virus. Shoulder of the fruit is green, mild ribbing with deep oblate shape and it sets fruits upto $38^{\circ} \mathrm{C}$.

A field experiment was conducted as an on farm trial in different locations in Salem district during Kharif season of 2020 in tomato using hybrids TNAU Tomato Hybrid CO 4 and Arka Vishesh and with Sivam Hybrid as check hybrid. The experiment was laid out in a Randomized Block Design with seven replications. The mean performance of different traits such as plant height, days to first flowering, days to first harvest, number of fruits per cluster, fruit yield per pland, yield per hectare, net returns per hectare and benefit cost ratio have been recorded and data was subjected to statistical analysis (Panse and Sukhatme, 1985).

\section{RESULTS AND DISCUSSION}

The results (Table 1.) showed that TNAU Tomato Hybrid CO 4 recorded an average yield of 95 t/ha and Arka Vishesh recorded an average yield of around $87 \mathrm{t} / \mathrm{ha}$. The private hybrid Sivam recorded an yield of $62 \mathrm{t} / \mathrm{ha}$. TNAU Tomato Hybrid CO 4 recorded more average number of fruits per cluster (5-6) and higher fruit yield per plant (2.5 to $2.75 \mathrm{~kg}$ ) when compared to Arka Vishesh with average number of fruits per cluster (4-5) and higher fruit yield per plant (2.25 to $2.50 \mathrm{~kg}$ ). The seed cost of the private variety grown by the farmer is higher and the hybrids such as TNAU CO4 and 
International Advanced Research Journal in Science, Engineering and Technology

Vol. 8, Issue 8, August 2021

DOI: 10.17148/IARJSET.2021.8881

IIHR hybrid Arka Vishesh performed better with regard to higher cost benefit ratio (BCR for TNAU Tomato Hybrid CO 4 is 1:3.81 and for Arka Vishesh 1:3.41 ). But the market preference for COTH4 is comparatively higher due to the large sized fruits with green shoulder at breaker stage with more acidity $(0.7 \%)$ which enhances the consumer preference in the market.

Table 1. Per se performance of different hybrids of tomato in Salem Districts

\begin{tabular}{|c|c|c|c|c|c|c|c|c|}
\hline $\begin{array}{c}\text { Technology } \\
\text { Option }\end{array}$ & $\begin{array}{c}\text { Plant } \\
\text { height } \\
\text { (cm) }\end{array}$ & $\begin{array}{c}\text { Days to } \\
\text { first } \\
\text { flowering }\end{array}$ & $\begin{array}{c}\text { Days to } \\
\mathbf{5 0 \%} \\
\text { flowering }\end{array}$ & $\begin{array}{c}\text { Number } \\
\text { of fruits } \\
\text { per } \\
\text { cluster }\end{array}$ & $\begin{array}{c}\text { Yield } \\
\text { per } \\
\text { plant } \\
\text { (kg) }\end{array}$ & $\begin{array}{c}\text { Yield } \\
\text { (t/ha) }\end{array}$ & $\begin{array}{c}\text { Net } \\
\text { Returns(Rs. in } \\
\text { lakh./ha) }\end{array}$ & $\begin{array}{c}\text { B:C } \\
\text { ratio }\end{array}$ \\
\hline $\begin{array}{l}\text { TO 1-TNAU } \\
\text { Tomato } \\
\text { Hybrid CO4 }\end{array}$ & 90 & 32 & 36 & 5.5 & 2.50 & 95 & 380000 & 3.81 \\
\hline $\begin{array}{l}\text { TO 2- Arka } \\
\text { Vishesh }\end{array}$ & 92 & 33 & 37 & 4.5 & 2.25 & 87 & 326000 & 3.41 \\
\hline $\begin{array}{l}\text { FP-Sivam } \\
\text { hybrid }\end{array}$ & 96 & 35 & 40 & 4.5 & 2.15 & 62 & 217000 & 2.55 \\
\hline Mean & 93.14 & 33.3 & 37.6 & 5.02 & 2.29 & 81.3 & & \\
\hline CD5\% & 1.77 & 1.03 & 0.95 & 0.37 & 0.11 & 1.26 & & \\
\hline CD1\% & 2.49 & 1.44 & 1.33 & 0.51 & 0.16 & 1.76 & & \\
\hline SEd & 0.81 & 0.47 & 0.43 & 0.17 & 0.05 & 0.58 & & \\
\hline CV(\%) & 1.6 & 2.65 & 2.16 & 6.26 & 4.28 & 1.3 & & \\
\hline
\end{tabular}

In general, apart from higher yield in TNAU tomato hybrid CO 4, the consumers preference if more for it than Arka Vishesh hybrid and hence marketability is also comparatively more easier and better in TNAU Tomato Hybrid CO 4 than Arka Vishesh and Sivam Hybrid.

Photos

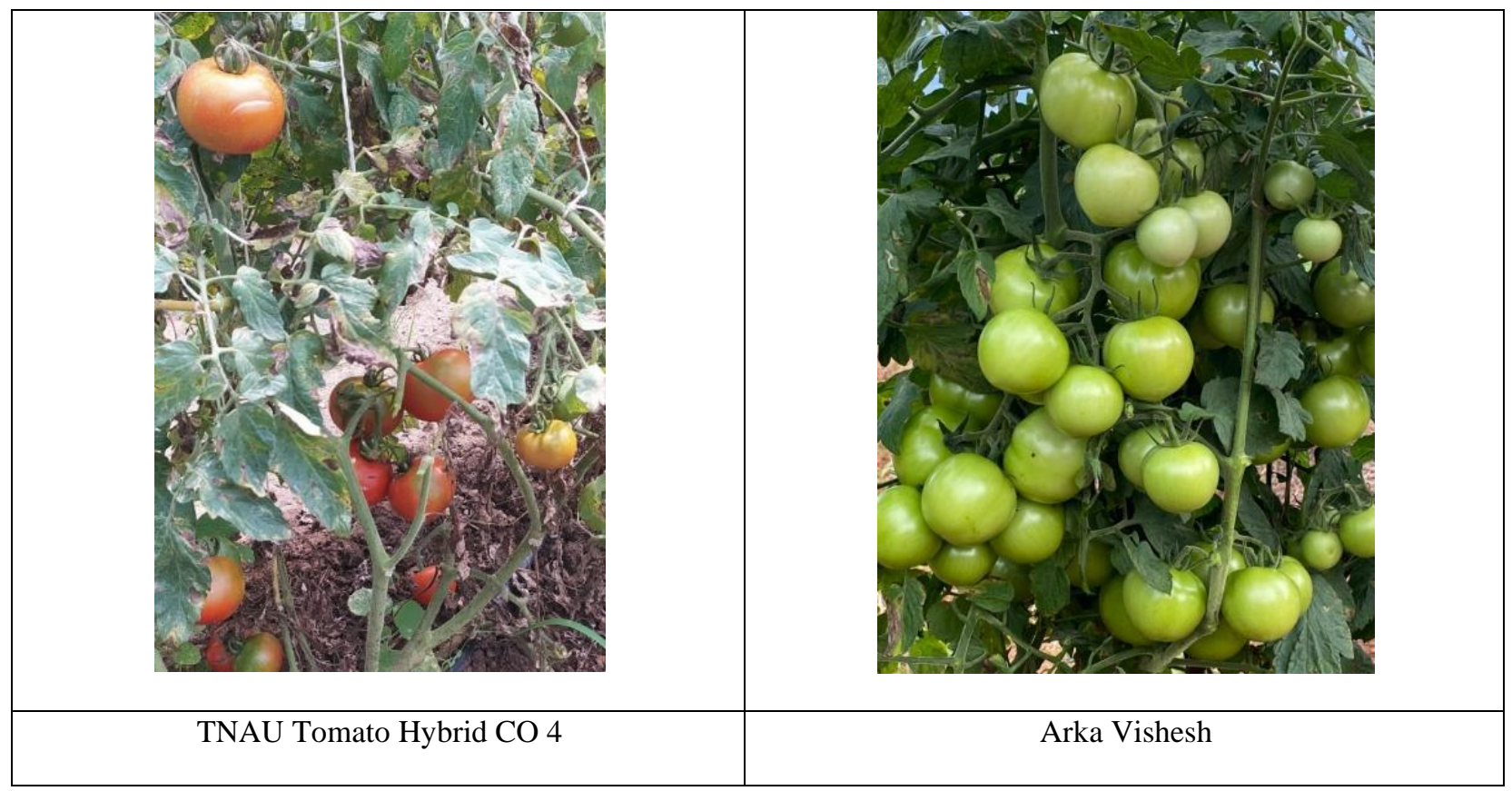


Vol. 8, Issue 8, August 2021

DOI: 10.17148/IARJSET.2021.8881

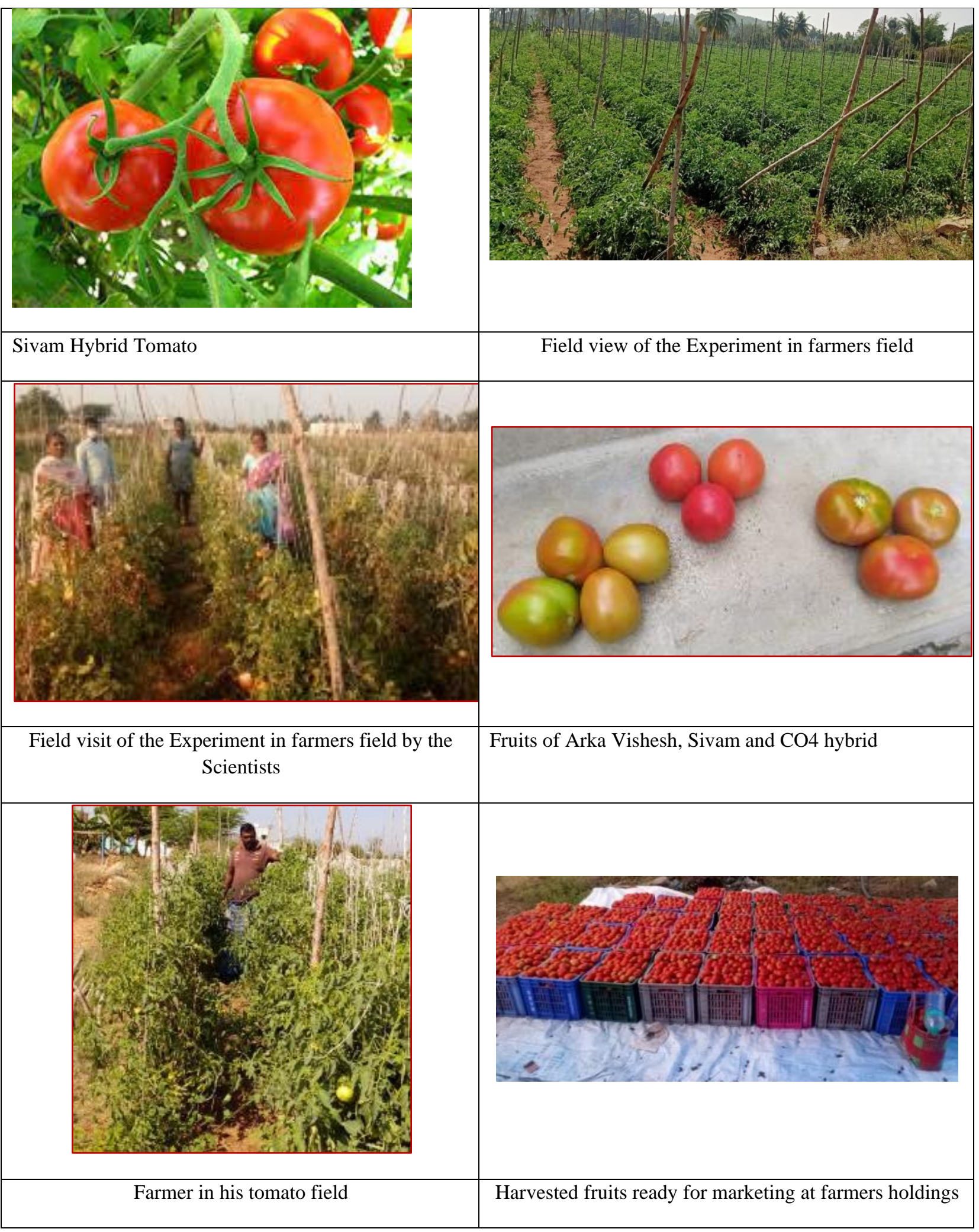




\section{International Advanced Research Journal in Science, Engineering and Technology}

Vol. 8, Issue 8, August 2021

\section{DOI: $10.17148 / I A R J S E T .2021 .8881$}

\section{CONCLUSION}

In Salem District of Tamil Nadu the TNAU Tomato Hybrid CO 4 recorded higher fruit yield of 95 t/ha whereas the Arka Vishesh recorded an yield of 87 t/ha. Hence TNAU Tomato Hybrid CO 4 hybrid is suitable for Salem farmers to get higher yield in tomato as well as higher net income and benefit cost ratio.

\section{REFERENCES}

1. Gupta. A.J., Chattoo, M.A. and Lal, S. 2015. Drip irrigation and fertigation tecthnology for improved yield, quality, water and fertilizer use efficiency in hybrid tomato. Journal of agri-search 2(2):94-99.

2. Pansem V.G. and Sukhatme, P.V. 1985. Statistical methods of agricultural workers. Indian Council of Agricultural Research (ICAR), 87-

3. $\quad$ Rick, C.M., 1978. The tomato. Scientific American. 239:76-87.

4. Shankar. A, Reddy, R.V.S.K., Sujatha. M, and Pratap. M, 2015. Development of superior $\mathrm{F}_{1}$ hybrids for cmmercial exploitation in tomato (Solanum lycopersicon L.), International Journal of Farm Science, Vol.4(2):58-69.

5. Triveni. D, Saidaiah, P., Ravinder Reddy. K, and Pandravada, S.R., 2017. Mean performance of the parents and hybrids for yield and yield contributing traits in tomato (Solanum lycopersicon L.), " International Journal of Current Microbiology and applied Sciences, Vol.6(11):613-619.

6. Vilas. C.A, Rana, M.K, Dhankar. S.K, Vikash Kumar and Yadav, N, 2015. Studies on combining ability analysis for yield and yield related traits in tomato (Solanum lycopersicon L.), Enzyme Engineering, Vol.4(2):1-5. 